\title{
Clonal Analysis of T Lymphocytes in the Acquired Immunodeficiency Syndrome Evidence for an Abnormality Affecting Individual Helper and Suppressor T Cells
}

\author{
Joseph B. Margolick, David J. Volkman, H. Clifford Lane, and Anthony S. Fauci \\ Laboratory of Immunoregulation, National Institute of Allergy and Infectious Diseases, \\ National Institutes of Health, Bethesda, Maryland 20205
}

\begin{abstract}
Purified helper-inducer (T4+) and suppressor-cytotoxic (T8+) lymphocytes from eight patients with acquired immunodeficiency syndrome (AIDS) and eight healthy heterosexual donors were examined by limiting dilution analysis for their ability to be clonally expanded. It was demonstrated that viable $\mathrm{T} 4+$ and T8+ lymphocytes from patients with AIDS had markedly reduced proportions of clonable cells compared to the healthy donors (T4 $=1: 255$ vs. 1:34, $P=0.06 ; T 8=1: 355$ vs. 1:55, $P=0.01)$. However, the cloned $T$ cells that were obtained from the patients with AIDS demonstrated normal proliferation in response to phytohemagglutinin and alloantigen, and normal ability to help or suppress pokeweed mitogen-driven IgG synthesis. These results strongly suggest that, in addition to a quantitative diminution of T4+ lymphocytes in AIDS, there is an intrinsic functional defect in the surviving $\mathrm{T4}+$ and $\mathrm{T} 8+$ lymphocytes, which is reflected by a severe decrease in their potential for clonal expansion.
\end{abstract}

\section{Introduction}

The acquired immunodeficiency syndrome (AIDS) ${ }^{1}$ is a recently recognized condition characterized clinically by the development of opportunistic infections and/or unusual neoplasms in previously healthy patients with no antecedent immune deficiency (1-5). The infections are frequently due to protozoal, viral, fungal, or unusual bacterial organisms (6), and their occurrence indicates a profound defect in cellular immunity (3-5). Similarly, the neoplasms that occur in AIDS, including Kaposi's sarcoma and B cell lymphoma, also have an increased incidence in patients with other forms of cellular immunodeficiency $(7,8)$.

Laboratory investigation of patients with AIDS has confirmed the presence of marked numerical and functional abnormalities in the cellular immune system, including diminished numbers $(9,10)$ and function (11) of circulating helperinducer (T4+) $\mathrm{T}$ cells, impairment or absence of delayed type hypersensitivity skin test responses (3-5, 12-14), decreases in mixed lymphocyte and mitogen responses $(3,9,11,15)$,

Address reprint requests to Dr. Margolick, National Institutes of Health, Bldg. 10, Rm. 11B-13, Bethesda, MD 20205.

Received for publication 29 October 1984 and in revised form 29 March 1985.

1. Abbreviations used in this paper: AIDS, acquired immunodeficiency syndrome; HTLV, human T cell lymphotropic virus; IL-2, interleukin 2; LAV, lymphadenopathy-associated virus; PHA, phytohemagglutinin.

The Journal of Clinical Investigation, Inc.

Volume 76, August 1985, 709-715 diminished production of interleukin 2 (IL-2) and other lymphokines (16-18), and low or absent antigen-specific responses both in vivo and in vitro $(4,19)$. In addition, recent serologic and virologic studies have shown that most, if not all, patients with AIDS and pre-AIDS conditions are infected with cytopathic retroviruses, either human $T$ lymphotropic virus III (HTLV-III) $(20,21)$ or lymphadenopathy-associated virus (LAV) (22). Both of these viruses infect $T$ lymphocytes, especially the $\mathrm{T} 4+$ (helper-inducer) subset $(20,23)$, and it is likely that they are in fact identical viruses. Thus, the evidence is compelling that T-cell alterations are fundamental to the pathogenesis of AIDS.

The assessment of T-cell function in AIDS has been complicated by the great variability in the numbers and proportions of helper-inducer (T4t) and suppressor-cytotoxic $(\mathrm{T} 8+) \mathrm{T}$ cells that may be present in the peripheral blood of different patients. Thus, studies on peripheral blood cells from patients with AIDS have not resolved the question of whether the immune abnormalities in AIDS are entirely secondary to abnormal proportions and numbers of $T$ lymphocytes, or whether an intrinsic abnormality of individual $\mathrm{T}$ cells is also present. A few studies have examined purified populations of T4+ and T8+ lymphocytes from patients with AIDS (11), but again the question of the functional capability of individual $T$ cells has not been directly addressed.

The goal of the present study was to examine the function of cloned rather than heterogeneous populations of $T$ cells or unfractionated peripheral blood mononuclear cells in patients with AIDS. It has previously been demonstrated that a high proportion of normal human peripheral blood $T$ cells can be clonally expanded in vitro (24). Therefore, we compared the clonability of both helper and suppressor $T$ cells from AIDS patients with that of $T$ cells from normal donors. In addition, because cloned $T$ cells reflect the functional properties of their progenitor cells, we compared clones from patients with AIDS and clones from normal donors in terms of their responses to various proliferative stimuli, as well as their ability to provide help or suppression for immunoglobulin (Ig) synthesis.

\section{Methods}

Patients. Eight patients with AIDS, three healthy male homosexual volunteers, and 11 healthy heterosexual volunteers were studied. The clinical characteristics of the patients with AIDS are given in Table I. With the exception of patient 4 , these patients were clinically stable, i.e., they were not hospitalized and were receiving minimal drug therapy. In general, the patients with AIDS either had Kaposi's sarcoma and were not on specific treatment, or had recently recovered from Pneumocystis carinii pneumonia with completion of an adequate course of antibiotic therapy.

Purification of peripheral blood cells. In each of eight experiments, cells from one patient with AIDS and one healthy heterosexual donor were studied simultaneously. In each of three separate experiments, 
cells from one healthy male homosexual and one healthy heterosexual donor were studied. Heparinized peripheral blood was obtained from the healthy subjects; however, because of the severely decreased numbers of circulating helper $T$ cells in the patients with AIDS (Table I), peripheral blood lymphocytes from these patients were obtained in large numbers $\left(200-400 \times 10^{6}\right)$ by manual plasmapheresis $(25)$. Mononuclear cells were separated by density gradient centrifugation on Hypaque-Ficoll (26), and purified $T$ cells were obtained by rosetting mononuclear cells with sheep erythrocytes coated with 2-aminoethylisothiouronium as described (27). The cells obtained were $>95 \%$ rosette positive.

Fractions enriched in $\mathrm{T} 4+$ and $\mathrm{T} 8+$ cells were then obtained by either negative or positive selection. For negative selection, $T$ cells were treated with mouse anti-OKT8 or anti-OKT4 monoclonal antibody (Ortho Diagnostics, Raritan, NJ) followed by rabbit complement as described (28). This procedure resulted in purity of $>90 \%$ for the normal T4+ and T8+ cells, 80-90\% for the AIDS T8+ cells, and 40$60 \%$ for the AIDS T4+ cells. For positive selection, an affinity rosetting technique was used. Briefly, ox erythrocytes were coated with affinitypurified goat anti-mouse Ig (Boehringer Mannheim Biochemicals, Indianapolis, IN) using a chromium chloride coupling technique (29). $\mathrm{T}$ cells were treated with either anti-OKT4 or anti-OKT8 at 0.05 $\mu 1 / 10^{6}$ cells for $45 \mathrm{~min}$ at $4^{\circ} \mathrm{C}$ and added at $10^{7} / \mathrm{ml}$ to $2 \mathrm{ml}$ of $5 \%$ human serum albumin (Cutter Biological, Berkeley, CA) and $5 \mathrm{ml}$ of $2 \%$ antibody-coated ox erythrocytes. Preparations were centrifuged at $1,600 \mathrm{rpm}$ at $4^{\circ} \mathrm{C}$ for $5 \mathrm{~min}$, incubated for $45 \mathrm{~min}$ at $4^{\circ} \mathrm{C}$, and resuspended gently. Rosette-positive and -negative cells were then separated over a Hypaque-Ficoll density gradient, and the ox erythrocytes were lysed with ammonium chloride. This procedure resulted in purity of $>90 \%$ for normal T4+ and T8+ cells and for AIDS T8+ cells; the AIDS T4+ cells consisted of $40-80 \%$ T4 + cells but $<10 \%$ contaminating T8+ cells. The relatively low purity of the T4+ cells obtained from the patients with AIDS is probably due to the low proportion of such cells in these patients (Table I); thus, the rosetting procedure used to purify T4+ cells is not $100 \%$ specific, and carryover of even a small fraction of the non-T4+ cells from each donor would lead to a relatively increased proportion of non-T4+ cells in the T4-enriched population from the AIDS patients.

For all experiments, the proportions of $\mathrm{T} 4+$ and $\mathrm{T} 8+$ cells in the starting populations were taken into account when calculating the number of cells plated per well.
Cloning procedures and determination of precursor frequency. For the cloning of T cells, the procedure of Moretta et al. (24) was used, with slight modification. Serial dilutions of viable (by trypan blue exclusion) lymphocytes were plated in 96-well round-bottomed microtiter plates. On the basis of preliminary experiments indicating the need to examine a wide range of precursor frequencies, cells were plated at $0.8,4,20$, and 100 cells per well in all experiments, and also at 500 cells per well in cultures not containing mitogen. The plated $\mathrm{T}$ cells were cultured in RPMI 1640 with glutamine, 10\% fetal calf serum, and gentamicin (complete medium); 4,500 rad-irradiated allogeneic mononuclear cells at $50-100 \times 10^{3}$ per well; and $20 \%$ IL-2containing supernatant (derived from MLA 144 cell line) (30). For optimal cloning conditions phytohemagglutinin (PHA, Burroughs Wellcome, Research Triangle Park, NC) was added to most cultures at a final concentration of $2 \mu \mathrm{g} / \mathrm{ml}$.

After 14-18 d of culture, the number of wells containing colonies (positive wells) was scored visually, and the percentage of negative wells was calculated. The precursor frequency, i.e., the average number of cells needed to generate a single clone, was determined by plotting the number of cells plated per well against the logarithm of the percent negative wells; according to one-hit Poisson statistics (31), the precursor frequency is equal to the cell density that would yield $37 \%$ negative wells. For further study, colonies having a $>90 \%$ probability of true clonality by Poisson statistics were selected at random and expanded in medium containing IL-2 and feeder cells, as described above.

Immunofluorescence. Lymphocytes were stained with the mouse monoclonal antibodies anti-OKT4 and anti-OKT8 (Ortho Diagnostics) and anti-Leu 8 (Becton, Dickinson \& Co., Oxnard, CA), by either indirect or direct immunofluorescence as described (28). Fluorescence was evaluated using either a fluorescence-activated cell sorter (FACS II, Becton, Dickinson \& Co., Mountain View, CA) or cytofluorograph (Becton, Dickinson \& Co.). For each marker, at least 10,000 cells were counted.

Analysis of proliferative responses to $\mathrm{PHA}$ and alloantigen. Lymphocytes were washed twice with RPMI to remove medium containing IL-2 and then resuspended at $10^{5} / \mathrm{ml}$ in complete medium; irradiated (4,500 rads) allogeneic unfractionated mononuclear cells, PHA (2 $\mu \mathrm{g} / \mathrm{ml}$ ), or both were added to the cultures. Cultures were pulsed with $1 \mu \mathrm{Ci}\left[{ }^{3} \mathrm{H}\right]$ thymidine after $48 \mathrm{~h}$, harvested on a MASH harvester after an additional $16 \mathrm{~h}$, and counted in a Beckman scintillation counter (Beckman Instrument Co., Palo Alto, CA). Stimulation indices were

Table I. Clinical Characteristics of Patients with AIDS

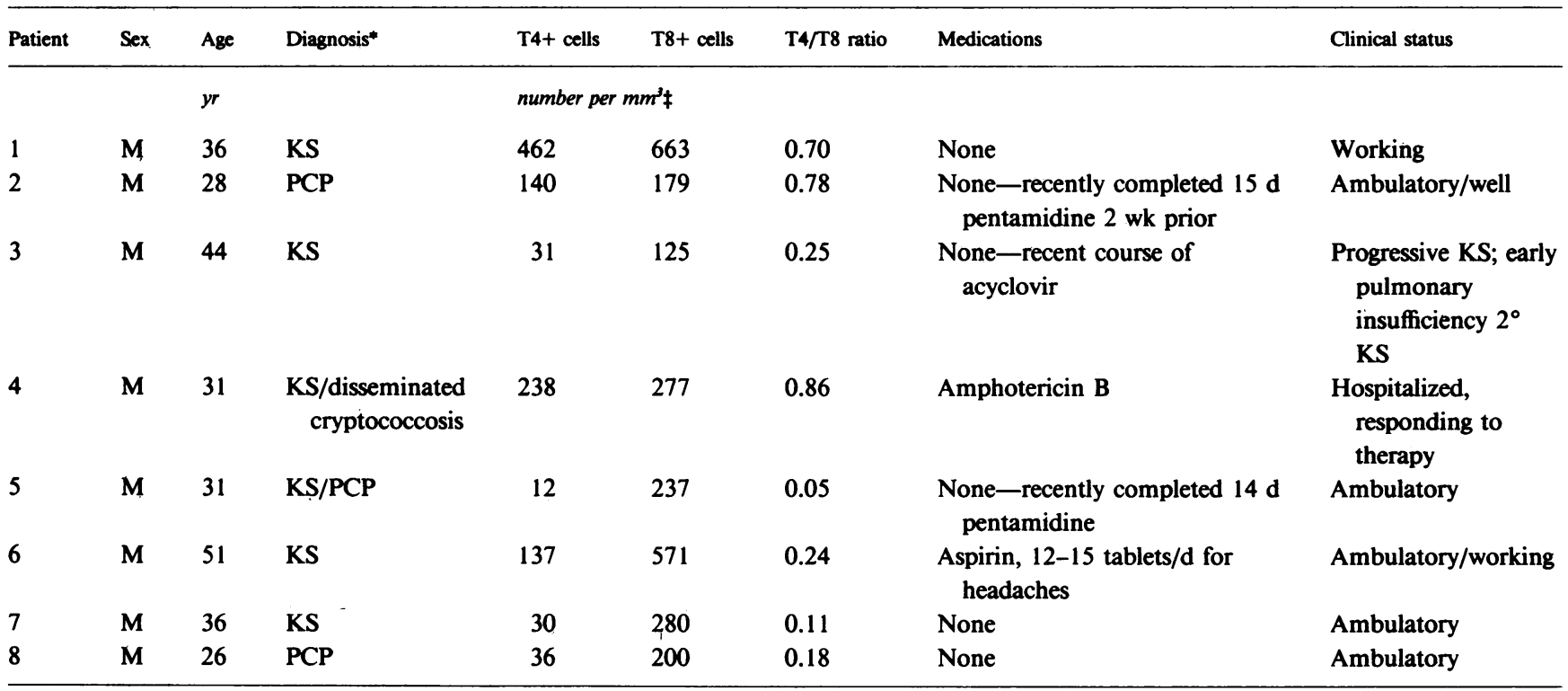

* KS, Kaposi’s sarcoma; PCP, Pneumocystis carinii pneumonia. $\quad \ddagger$ Normal ranges: T4+, 1,126-1,289; T8+, 369-447. 
calculated by dividing the counts per minute with mitogen or alloantigen by the counts per minute with media alone.

Assessment of functional T-cell help and suppression of Ig synthesis. T cells of known helper (T4) or suppressor (T8) phenotypes were added to allogeneic responder $B$ cells consisting of erythrocyte-rosettenegative peripheral blood mononuclear cells which had been depleted of monocytes by glass adherence. The responder B cells contained $<5 \%$ monocytes, and were adjusted to contain 5-10\% autologous $T$ cells. Cells were incubated with and without pokeweed mitogen (Gibco Laboratories, Grand Island, NY) at a final concentration of 1:200, and Ig production was measured by an enzyme-linked immunosorbent assay technique after 8-10 d in culture as previously described (32).

Statistical analysis. For comparisons of precursor frequencies of $\mathrm{T}$ cell subgroups (data in Tables II and III), geometric means for each subgroup were compared by subjecting the logged values of the individual experiments to a paired-sample $t$ test. This procedure was used because of the marked variation in the level of response among experiments, and also to stabilize the variation around the (logged) mean (33).

For comparisons of stimulation indices among groups of $\mathrm{T}$ cell clones (data in Fig. 2), the geometric means for each group were compared by subjecting the logged values of the individual indices to a two-sample (unpaired) $t$ test (33).

\section{Results}

Cloning efficiency of AIDS and normal lymphocytes. Compared to the normal donors, the patients with AIDS had a profound decrease in the number of $\mathrm{T} 4+$ and $\mathrm{T} 8+$ cells that were able to be clonally expanded. Fig. 1 shows the results of a representative cloning experiment performed under optimal cloning conditions, i.e., in the presence of PHA, and illustrates the markedly reduced numbers of both $\mathrm{T} 4+$ and $\mathrm{T} 8+$ clones obtained from the patient with AIDS relative to the normal donor. Overall, under these cloning conditions, patients with AIDS had markedly reduced numbers of clonable T4+ cells in seven of eight experiments (Table II $A$ ), and of clonable T8+ cells in seven of seven experiments (Table III $A$ ). The mean precursor frequency of $\mathrm{T} 4+$ lymphocytes from the patients with AIDS was 1:255, compared to 1:34 for the T4+ lymphocytes from the normal donors, a decrease of $86.6 \%$ (Table II $A, P=0.06$ ). Similarly, T8+ lymphocytes from the

CELLS PLATED PER WELL

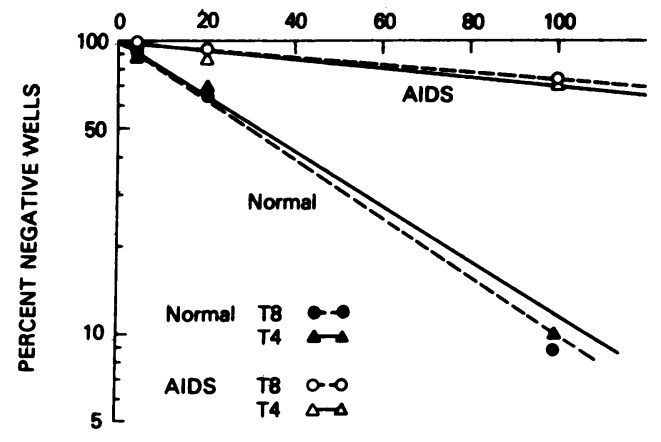

Figure 1. Limiting dilution cloning experiment on purified T4 and T8 cells from a patient with AIDS $(\Delta, 0)$ and a normal donor $(\Delta, \bullet)$, using cloning conditions including PHA. The straight line indicates that the data conform to the one-hit Poisson distribution. Precursor frequencies, as estimated from the number of cells per well yielding $37 \%$ negative wells, are as follows: normal T4 $=1: 46$, normal T8 $=1: 40$, AIDS T4 $=1: 276$, AIDS T8 $=1: 368$.
Table II. Precursor Frequencies of Clonable T4+ Cells

\begin{tabular}{|c|c|c|c|c|c|c|}
\hline \multirow[b]{2}{*}{ Experiment ${ }^{*}$} & \multirow[t]{2}{*}{$(A)$} & \multicolumn{2}{|l|}{ +PHA } & \multirow[t]{2}{*}{ (B) } & \multicolumn{2}{|l|}{-PHA } \\
\hline & & Normal & AIDS & & Normal & AIDS \\
\hline 1 & & $5,000 \S$ & 200 & & - & - \\
\hline 2 & & 1 & 130 & & - & - \\
\hline 3 & & 5 & 148 & & 530 & 3,285 \\
\hline 4 & & 1 & 1,000 & & 68 & 1,020 \\
\hline 5 & & 240 & 552 & & - & - \\
\hline 6 & & 40 & 276 & & - & - \\
\hline 7 & & 200 & 2,220 & & - & - \\
\hline 8 & & 4 & 14 & & 64 & 2,000 \\
\hline Geometric mean & & 34 & 255 & & 132 & 1,894 \\
\hline$P$ value & & \multicolumn{2}{|c|}{0.06} & & \multicolumn{2}{|c|}{0.03} \\
\hline
\end{tabular}

* T4+ cells purified by negative selection (experiments 1-4) or positive selection (experiments 5-8) as described in text.

$\ddagger+$, cultures with PHA added; -, cultures without PHA.

$\S$ Values indicate reciprocal of precursor frequency.

"-, not done.

patients with AIDS had a mean precursor frequency of 1:355, as compared to 1:56 for $\mathrm{T} 8+$ lymphocytes from the normal donors, a decrease of $84.2 \%$ (Table III $A, P=0.01$ ). In contrast to the marked decrease in the total number of clonable $T$ cells in the patients with AIDS, the relative precursor frequencies of clonable $\mathrm{T} 4+$ versus $\mathrm{T} 8+$ cells were similar for normal donors (1:34 vs. 1:55) and AIDS patients (1:255 vs. 1:355).

The omission of PHA from the cloning cultures decreased the precursor frequencies by an order of magnitude for both AIDS and normal T cells (Tables II $B$, III $B$ ). However, in all experiments cloning efficiencies for both $\mathrm{T} 4+$ and $\mathrm{T} 8+\mathrm{T}$ cells from patients with AIDS were still greatly reduced compared to cells from normal donors, and under these experimental conditions, the overall cloning efficiencies of both $\mathrm{T} 4+$ and T8+ cells from patients with AIDS were reduced by $>90 \%$ compared to the corresponding cells from healthy donors.

Table III. Precursor Frequencies of Clonable T8+ Cells

\begin{tabular}{|c|c|c|c|c|c|c|}
\hline \multirow[b]{2}{*}{ Experiment* } & \multirow[t]{2}{*}{$(A)$} & \multicolumn{2}{|l|}{ +PHA } & \multirow[t]{2}{*}{$(B)$} & \multicolumn{2}{|l|}{$-\mathrm{PHA}$} \\
\hline & & Normal & AIDS & & Normal & AIDS \\
\hline 1 & & $1,050 \$$ & 1,200 & & - & - \\
\hline 2 & & 2 & 80 & & - & - \\
\hline 3 & & 25 & 31 & & 650 & 4,600 \\
\hline 4 & & 10 & 170 & & 260 & 4,000 \\
\hline 5 & & 280 & 1,288 & & - & - \\
\hline 6 & & 44 & 368 & & - & - \\
\hline 7 & & 260 & 2,000 & & - & - \\
\hline Geometric mean & & 55 & 355 & & 411 & 4,289 \\
\hline$P$ value & & \multicolumn{2}{|c|}{0.01} & & \multicolumn{2}{|c|}{0.21} \\
\hline
\end{tabular}

* T8+ cells purified by negative selection (experiments $1-4$ ) or positive selection (experiments 5-7) as described in text. $\ddagger+$, cultures with PHA added; -, cultures without PHA. $\S$ Values indicate reciprocal of precursor frequency.

"-, not done. 


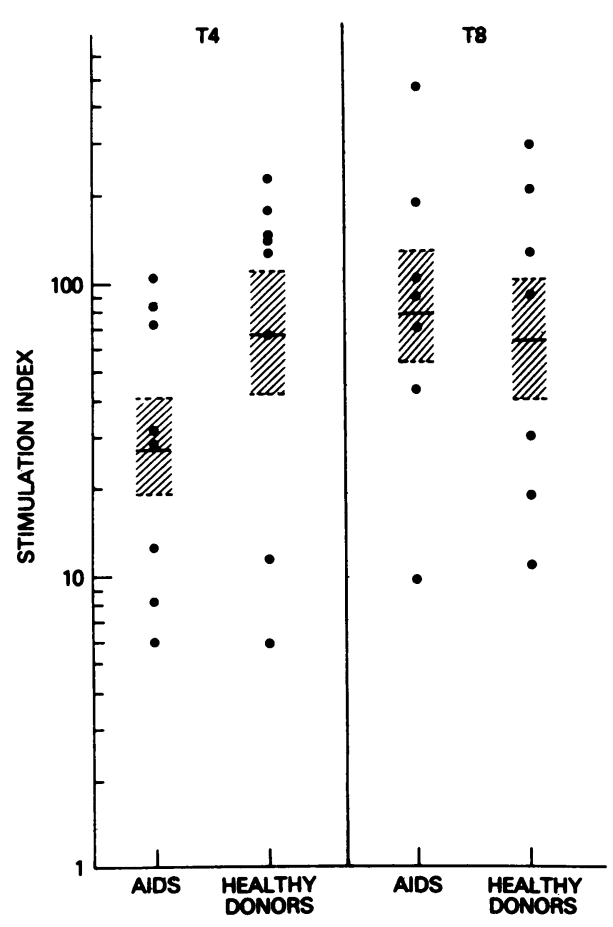

Figure 2. Stimulation indices of T4+ and T8+ T cell clones from normal donors and patients with AIDS. Shaded areas = mean \pm SEM. Stimulation index $=\left[{ }^{3} \mathrm{H}\right]$ thymidine uptake in media with PHA/ $\left[{ }^{3} \mathrm{H}\right]$ thymidine uptake in media alone.

Phenotyping of clones by immunofluorescence staining showed that for both AIDS and normal lymphocytes, starting preparations enriched for $\mathrm{T} 4+$ and $\mathrm{T} 8+$ lymphocytes yielded $>95 \%$ clones of the same phenotype and all clones exhibited either the $\mathrm{T} 4+$ or $\mathrm{T} 8+$ phenotype (data not shown). Thus, the procedures for enriching $\mathrm{T}$-cell fractions for either $\mathrm{T} 4+$ cells or $\mathrm{T} 8+$ cells were effective in preselecting the phenotypes of the cloned cells and provided ample clones of both phenotypes for further analysis.

Of the T4+ clones tested for the Leu 8 marker, 13 of 17 (76\%) from normal donors were positive, compared to 8 of 8 $(100 \%)$ from the patients with AIDS $(P>0.10)$. For the T8+ clones, the number of Leu $8+$ clones was eight of nine from the normal donors and six of six from the patients with AIDS $(P>0.10)$. Thus, Leu 8 expression on AIDS T4t and T8+ clones was not statistically different from that on the normal clones.

PHA responsiveness of the clones. PHA responses of the 30 clones tested are shown in Fig. 2. There was no significant difference between the stimulation indices for $\mathrm{T} 8$ clones from patients with AIDS and those from healthy donors in response to PHA stimulation. There was an apparent decrease in PHAinduced proliferation of the AIDS T4+ clones (mean stimulation index $=27$ ) compared to the normal T4+ clones (mean stimulation index $=67$ ); however, this difference was not statistically significant $(P>0.10)$.

Helper and suppressor function of the clones. All clones studied from both normals and patients with AIDS had the helper or suppressor function that would have been expected on the basis of T4/T8 phenotype. Addition of T4+ clones in graded numbers to $\mathrm{B}$ cell-enriched allogeneic responder cells augmented Ig production, whereas addition of T8+ clones in graded numbers resulted in decreased Ig production. In all, 20 clones (12 helper and 8 suppressor) from AIDS patients were tested. A representative experiment involving two helper and two suppressor clones is shown in Fig. 3. Although Ig production was increased in the presence of small numbers of $\mathrm{T} 8+$ cells (Fig. $3 \mathrm{~b}$ ), addition of greater numbers of such cells resulted in suppression. Cultures performed in the absence of pokeweed mitogen yielded $<100 \mathrm{ng} / \mathrm{ml}$ of $\mathrm{Ig}$.

Alloreactivity of clones. 15 clones from normal donors and 17 from patients with AIDS were tested for alloreactivity against randomly selected allogeneic mononuclear cells. Of these, $11(73 \%)$ of the normal clones and $4(24 \%)$ of the AIDS

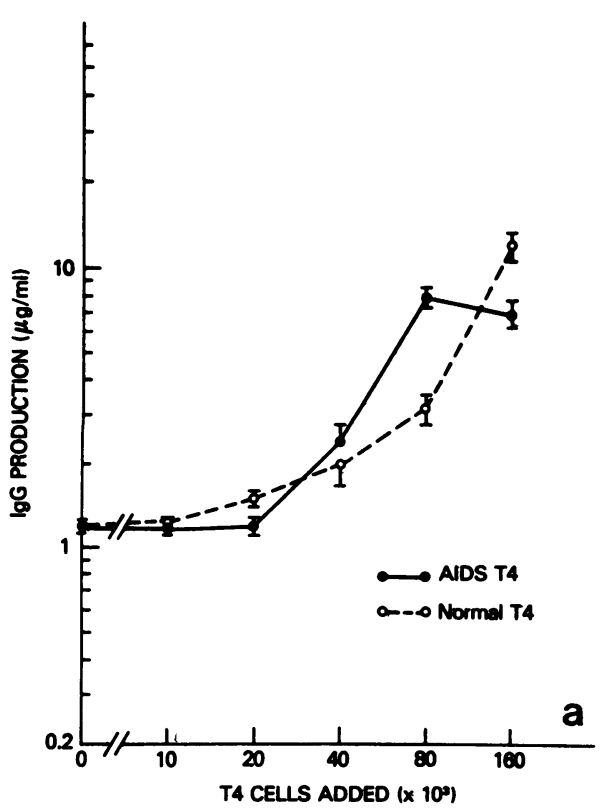

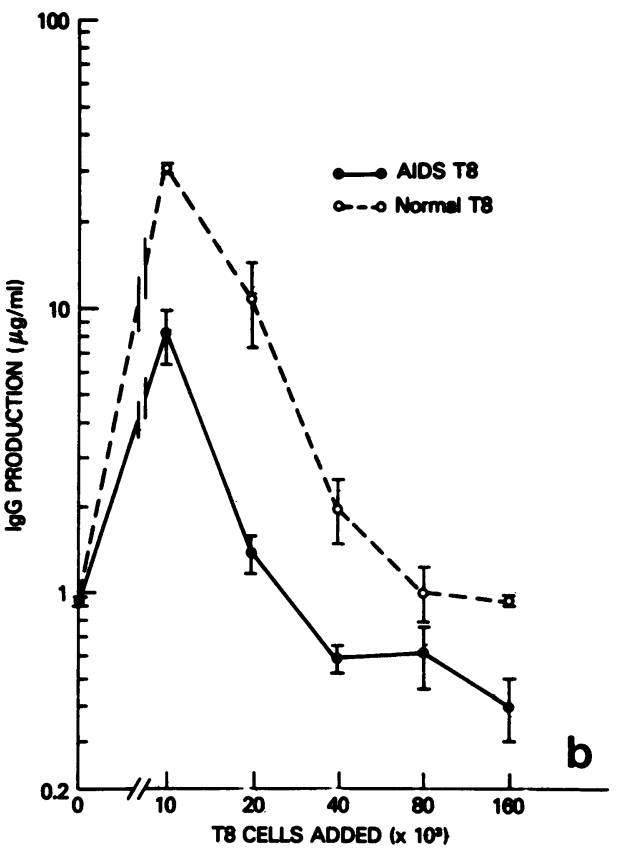

Figure 3. Functional capabilities of T4+ and $\mathrm{T} 8+$ clones from a patient with AIDS and a normal donor when added to a system of pokeweed mitogen-driven Ig production. $(A) \mathrm{T} 4+$ clones. Both AIDS and normal T4+ clones augment IgG production as greater numbers of cells are added. $(B) \mathrm{T} 8+$ clones. Both AIDS and normal T8+ clones suppress IgG production as greater numbers of cells are added. 
clones demonstrated alloreactivity (data not shown). Thus, alloreactive $T$ cells were present in the patients with AIDS, although their frequency was significantly less than in the normal clones sampled $(P=0.05)$.

Precursor frequencies of lymphocytes from healthy male homosexuals. $\mathrm{T} 4+$ and $\mathrm{T} 8+$ lymphocytes from healthy male homosexuals had precursor frequencies comparable to lymphocytes from normal heterosexual donors (for $\mathrm{T} 4+$, mean $=1: 2.1$ vs. $1: 2.5$, respectively; for $\mathrm{T} 8+$, mean $=1: 3.0$ vs. 1 : 4.9 , respectively) (Table IV).

\section{Discussion}

The present study has provided the first direct evidence of a functional defect in individual $T$ cells in patients with AIDS. Specifically, viable $T$ cells from patients with AIDS gave rise to $\sim 85 \%$ fewer $T$ cell clones than $T$ cells from normal donors, and this profound cloning defect in AIDS $\mathrm{T}$ cells was present in both $\mathrm{T} 4+$ cells (87\% reduction in clonable cells) and in T8+ cells ( $84 \%$ reduction in clonable cells). It should be emphasized that the decreased cloning efficiency of $\mathrm{T}$ cells from patients with AIDS cannot be attributed to variability in numbers or proportions of circulating $\mathrm{T} 4+$ and $\mathrm{T} 8+$ cells from patient to patient for two reasons: $(a)$ the proportions of $\mathrm{T} 4+$ and $\mathrm{T} 8+$ cells in the cloning populations in each experiment were known and were used in calculating precursor frequencies, and $(b)$ under limiting-dilution cloning conditions, the clonability of each $\mathrm{T}$ cell is independent of any interacting or cooperating lymphocytes. In addition, because seven of eight patients with AIDS were neither acutely ill nor receiving drug therapy at the time of study, the decreased cloning efficiency of their lymphocytes is unlikely to be related to drug effects or general debilitation.

Therefore, it is most likely that the reduced cloning efficiency of lymphocytes from patients with AIDS reflects an intrinsic defect in their ability to proliferate and expand clonally even though they appear viable by the criterion of trypan blue exclusion. Such a defect could be due to a viral infection, in that certain RNA viruses such as measles and influenza have been demonstrated in vitro to impair proliferative responses of viable lymphocytes (34). The retroviruses HTLV-III (20, 21) and LAV (22), which have been isolated from most, if not all, patients with AIDS and AIDS-related syndromes, have been shown to be cytopathic for human $T$ lymphocytes, but

Table IV. Precursor Frequencies for Clonable T Lymphocytes from Healthy Homosexual and Heterosexual Donors

\begin{tabular}{|c|c|c|c|c|}
\hline \multirow[b]{2}{*}{ Experiment } & \multicolumn{2}{|l|}{ T4t } & \multicolumn{2}{|l|}{ T8+ } \\
\hline & Homosexual & Heterosexual & Homosexual & Heterosexual \\
\hline 1 & $3.8^{*}$ & 3.2 & $-\ddagger$ & - \\
\hline 2 & 0.9 & 3.3 & 2.6 & 2.5 \\
\hline 3 & 2.8 & 1.5 & 3.5 & 9.5 \\
\hline Mean & 2.1 & 2.5 & 3.0 & 4.9 \\
\hline$P$ value & NS§ & & NS & \\
\hline
\end{tabular}

* Values indicate reciprocal of precursor frequencies.

$\ddagger$ - not done.

$\S \mathrm{NS}$, not significant $=P>0.10$. the decreased cloning efficiency of both $\mathrm{T} 4+$ and $\mathrm{T} 8+$ cells demonstrated in the present study cannot be readily explained by a direct infection with HTLV/LAV in that these viruses are selectively infective for T4 cells and have not been shown to infect T8 cells (Popovic, M., personal communication) (23). Thus, it appears that other factors must be involved to account for the decreased cloning efficiencies of both $\mathrm{T} 4+$ and T8+ cells. The other infectious agents clinically evident in the AIDS patients studied were Epstein-Barr virus and cytomegalovirus. Epstein-Barr virus has not been reported to infect $T$ cells, but cytomegalovirus has recently been reported to be capable of abortively infecting small proportions of normal human $T$ lymphocytes of both $\mathrm{T} 4+$ and $\mathrm{T} 8+$ subclasses $(35,36)$, as well as inhibiting proliferative responses of lymphocytes in infected cultures of mononuclear cells (36). Thus, it is possible that cytomegalovirus infection may be related to the present findings. Therefore, the clonable $T$ cells from patients with AIDS could represent a small residual population of uninfected $T$ cells, and/or $T$ cells in an early stage of infection. In support of this interpretation is the observation that the clonable $T$ cells from patients with AIDS appeared normal in the functions studied, including mitogen responsiveness, alloreactivity, and ability to provide help or suppression in a mitogen-driven allogeneic system.

Several other mechanisms should be considered as possibly contributing to the decreased cloning efficiency of T8+ cells as well as $\mathrm{T} 4+$ cells from patients with AIDS. First, patients with AIDS have a relatively increased proportion of circulating activated T8+ cells (37), and it could be postulated that these cells which had been activated in vivo might have a decreased cloning efficiency compared to resting $T$ cells that have been activated in vitro by mitogen. However, there is no evidence to support such a phenomenon; moreover, the extent of the increase in activated $\mathrm{T} 8+$ cells (up to $25 \%$ of $\mathrm{T} 8+$ cells) is too small to account for the $84 \%$ decrease in cloning efficiency of $\mathrm{T} 8+$ cells observed in this study, and also does not explain the similar decrease in clonability of $\mathrm{T} 4+$ cells from the patients with AIDS. Moreover, AIDS T cells also had greatly decreased precursor frequencies in cultures not containing PHA, conditions that may provide a measurement of in vivoactivated $T$ cells which can respond to IL-2 without PHA activation in vitro (38). These data suggest that the cloning efficiency of even in vivo-activated T cells in AIDS is markedly reduced compared to normal. Second, the $\mathrm{T}$ cells from patients with AIDS could lose their ability to respond to mitogen and to proliferate clonally for reasons not related to activation states or to infectious agents. Third, the possibility exists that not all $T$ cells are equally clonable; thus, the decreased precursor frequency of $T$ cells from patients with AIDS might simply reflect a depletion of the more clonable subpopulations of $\mathrm{T} 4+$ and $\mathrm{T} 8+$ cells. No differences in clonability among $\mathrm{T}$ cell subpopulations have been reported to date, although the report by Moretta et al. (24) that purified bulk T cells have cloning efficiencies of $\sim 1.00$ would suggest that virtually all normal $\mathrm{T}$ cells are clonable, at least under certain conditions. This point is discussed further below. In the present study, the proportion of $\mathrm{T} 4+$ clones that were Leu $8+$ was somewhat higher in the patients with AIDS (100\%) than in the normal donors $(76 \%)$, which would be consistent with an abnormality of T4+ Leu 8- cells in the patients with AIDS. However, no firm conclusion can be derived from these data because the number of clones studied was small and the percentage of 
Leu $8+$ cells in the purified $\mathrm{T} 4+$ and $\mathrm{T} 8+$ populations before cloning could not be ascertained for technical reasons. In any case, none of these possibilities detracts from the implication of an intrinsic cloning defect in both $\mathrm{T} 4+$ and $\mathrm{T} 8+$ lymphocytes from patients with AIDS.

There are no reported studies assessing the comparative cloning efficiencies of circulating $T$ lymphocytes in human disease. Several studies have investigated the ability of $T$ cells from patients with various diseases to form colonies in an agar tissue culture system (39-41), and colony formation has been reported to be diminished in patients with AIDS (42). However, it is controversial whether the colonies formed are derived from single progenitor cells (43). Therefore, it is unclear whether these latter findings reflect qualitative abnormalities of individual lymphocytes in the diseases studied, including AIDS.

The precursor frequencies of both T4 and T8 lymphocytes from healthy volunteers were generally less than one in the present study, in contrast to the results reported by Moretta et al. (24) in their experiments using unseparated T cells. Two technical factors might explain this discrepancy. First, we enriched our T-cell preparations for T4 and T8 cells, and the extra procedures required might have affected the cloning efficiency of the $T$ cells. Second, we scored positive wells by screening visually rather than by measuring the uptake of $\left[{ }^{3} \mathrm{H}\right]$ thymidine in each well, and accordingly we might have missed very small colonies in the cultures. However, neither of these differences in technique can account for the greatly decreased number of clones obtained from the AIDS patients compared to the healthy donors used as controls in each experiment.

This study illustrates the feasibility of identifying a functional impairment of individual $T$ cells in a particular subset by purifying specific T-cell subsets and evaluating their ability to expand clonally. This approach may be useful in the delineation of affected $T$ cell subpopulations in AIDS and in other diseases characterized by disordered cellular immunity. The importance of functional studies at the individual cell level is demonstrated by the finding in AIDS of a defect in the T8+ cells, even though the patients studied had only moderately abnormal numbers of $\mathrm{T} 8+$ cells and similarly purified $\mathrm{T} 8+$ cells in other studies have been found to suppress Ig production normally (11). Thus, cloning studies appear to detect impairments of $T$ cell function that would be missed by simple numerical enumeration or bulk functional assays. In addition, comparison of cloning efficiencies can yield a quantitative estimate of the number of affected cells, e.g., $\sim 85 \%$ for both T4 and T8 cells in the present study.

Thus, the present study has demonstrated a functional impairment affecting the great majority of surviving $T$ lymphocytes in the peripheral blood of AIDS patients. Such a qualitative impairment may contribute to the profound immunodeficiency present in patients with AIDS, many of whom have compromised immunity out of proportion to a relatively moderate reduction in T4+ lymphocytes. Further studies of lymphocyte function at the clonal level may help to clarify the nature of the immune defect in patients with AIDS.

\section{Acknowledgments}

The authors thank Drs. Henry Masur, Edward P. Gelmann, and Ronald G. Steis for clinical care provided to the patients; Ms. Gail
Whalen and Ms. Susan P. Allyn for expert technical assistance; Dr. Alain H. Rook for helpful discussions; Ms. Barbara Baird for the coordination of research studies; Dr. David Alling for assistance with the statistical analysis of the data; and Ms. Ann C. London for excellent editorial assistance.

\section{References}

1. Centers for Disease Control. 1981. Pneumocystis pneumoniaLos Angeles. Morbid. Mortal. Weekly Rep. 30:250-252.

2. Centers for Disease Control. 1981. Kaposi's sarcoma and Pneumocystis pneumonia among homosexual men-New York City and California. Morbid. Mortal. Weekly Rep. 25:305-308.

3. Masur, H., M. A. Michelis, J. B. Greene, I. Onorato, R. A. Vande Stouwe, R. S. Holzman, G. Wormser, L. Brettman, M. Lange, H. W. Murray, and S. Cunningham-Rundles. 1981. An outbreak of community-acquired Pneumocystis carinii pneumonia: initial manifestation of cellular immune dysfunction. N. Engl. J. Med. 305:14311438.

4. Gottlieb, M. S., R. Schroff, H. M. Schanker, D. O. Weisman, P. T. Fan, R. A. Wolf, and A. Saxon. 1981. Pneumocystis carinii pneumonia and mucosal candidiasis in previously healthy homosexual men: evidence of a new acquired cellular immunodeficiency. $N$. Engl. J. Med. 304:1425-1431.

5. Siegal, F. P., C. Lopez, G. S. Hammer, A. E. Brown, S. J. Kornfeld, J. Gold, J. Hasset, S. Z. Hirschman, C. CunninghamRundles, B. R. Adelsberg, D. M. Parham, M. Siegal, S. CunninghamRundles, and D. Armstrong. 1981. Severe acquired immunodeficiency in homosexual males, manifested by chronic perianal ulcerative herpes simplex lesions. N. Engl. J. Med. 305:1439-1444.

6. Selik, R. M., H. W. Haverkos, and J. W. Curran. 1984. Acquired immune deficiency syndrome (AIDS) trends in the United States, 1978-1982. Am. J. Med. 76:493-500.

7. Filipovich, A. H., B. D. Spector, and J. Kersey. 1980. Immunodeficiency in humans as a risk factor in the development of malignancy. Prev. Med. 9:252-259.

8. Schneck, S. A., and I. Penn. 1971. De novo brain tumours in renal transplant recipients. Lancet. 1:983-986.

9. Rogers, M. F., D. M. Morens, J. A. Stewart, R. M. Kaminski, T. J. Spira, P. M. Feorino, S. A. Larsen, D. P. Francis, M. Wilson, L. Kaufman, and the Task Force on AIDS. 1983. National case-control study of Kaposi's sarcoma and Pneumocystis carinii pneumonia in homosexual men. II. Laboratory results. Ann. Intern. Med. 99:151158.

10. Fahey, J. L., H. Prince, M. Weaver, J. Groopman, B. Visscher, K. Schwartz, and R. Detels. 1984. Quantitative changes in T helper or T suppressor/cytotoxic lymphocyte subsets that distinguish acquired immune deficiency syndrome from other immune subset disorders. Am. J. Med. 76:95-100.

11. Lane, H. C., H. Masur, L. C. Edgar, G. Whalen, A. H. Rook, and A. S. Fauci. 1983. Abnormalities of B-cell activation and immunoregulation in patients with the acquired immunodeficiency syndrome. N. Engl. J. Med. 309:453-458.

12. Mildvan, D., U. Mathur, R. W. Enlow, P. L. Romain, R. J. Winchester, C. Colp, H. Signman, B. R. Adelsberg, and I. Spigland. 1982. Opportunistic infections and immunodeficiency in homosexual men. Ann. Intern. Med. 96:700-704.

13. Greene, J. B., G. S. Sidhu, S. Lewin, J. F. Levine, H. Masur, M. S. Simberkoff, P. Nicholas, R. C. Good, S. B. Zolla-Pazner, A. A. Pollock, M. L. Tapper, and R. S. Holzman. 1982. Mycobacteriumavium-intracellulare: a cause of disseminated life-threatening infections in homosexuals and drug abusers. Ann. Intern. Med. 97:539-546.

14. Follansbee, S. E., D. F. Busch, C. B. Wofsy, D. L. Coleman, J. Gullet, G. P. Aurigemma, T. Ross, W. K. Hadley, and W. L. Drew. 1982. An outbreak of Pneumocystis carinii pneumonia in homosexual men. Ann. Intern. Med. 96:693-700.

15. Cunningham-Rundles, S., M. A. Michelis, and H. Masur. 1983. 
Serum suppression of lymphocyte activation in vitro in acquired immunodeficiency disease. J. Clin. Immunol. 3:156-165.

16. Ciobanu, N., K. Welte, G. Kruger, S. Venuta, J. Gold, S. P. Feldman, C. Y. Wang, B. Koziner, M. A. S. Moore, B. Safai, and R. Mertelsmann. 1983. Defective T-cell response to PHA and mitogenic monoclonal antibodies in male homosexuals with acquired immunodeficiency syndrome and its in vitro correction by interleukin $2 . J$. Clin. Immunol. 3:332-340.

17. Hauser, G. J., T. Bino, H. Rosenberg, V. Zakuth, E. Geller, and Z. Spirer. 1984. Interleukin-2 production and response to exogenous interleukin-2 in a patient with the acquired immune deficiency syndrome (AIDS). Clin. Exp. Immunol. 56:14-17.

18. Murray, H. W., B. Y. Rubin, H. Masur, and R. B. Roberts. 1984. Impaired production of lymphokines and immune (gamma) interferon in the acquired immunodeficiency syndrome. $N$. Engl. J. Med. 310:883-890.

19. Lane, H. C., H. Masur, G. Whalen, S. P. Allyn, and A. S. Fauci. 1984. Selective functional defects in purified lymphocyte subsets from patients with the acquired immunodeficiency syndrome. Clin. Res. 32:506A. (Abstr.)

20. Gallo, R. C., S. Z. Salahudin, M. Popovic, G. M. Shearer, M. Kaplan, B. F. Haynes, T. J. Palker, R. Redfield, J. Oleske, B. Safai, G. White, P. Foster, and P. D. Markham. 1984. Frequent detection and isolation of cytopathic retroviruses (HTLV-III) from patients with AIDS and at risk for AIDS. Science (Wash. DC). 224:500-502.

21. Sarngadharan, M. G., M. Popovic, L. Burch, J. Schüpbach, and R. C. Gallo. 1984. Antibodies reactive with human T-lymphotropic retroviruses (HTLV-III) in the serum of patients with AIDS. Science (Wash. DC). 224:506-508.

22. Kalyanaraman, V. S., C. D. Cabradilla, J. P. Getchell, R. Narayanan, E. H. Braff, J.-C. Chermann, F. Barré-Sinoussi, L. Montagnier, R. J. Spira, J. Kaplan, D. Fishbein, H. W. Jaffe, J. W. Curran, and D. P. Francis. 1984. Antibodies to the core protein of lymphadenopathy-associated virus (LAV) in patients with AIDS. Science (Wash. DC). 225:321-323.

23. Klatzmann, D., F. Barré-Sinoussi, M. T. Nugeyre, C. Dauguet, E. Vilmer, C. Griscelli, F. Brun-Vezinet, C. Rouzious, J. C. Gluckman, J.-C. Chermann, and L. Montagnier. 1984. Selective tropism of lymphadenopathy associated virus (LAV) for helper-inducer $T$ lymphocytes. Science (Wash. DC). 225:59-63.

24. Moretta, A., G. Pantaleo, L. Moretta, M.-C. Mingari, and C. Cerottini. 1983. Quantitative assessment of pool size and subset distribution of cytolytic $T$ lymphocytes within human resting or alloactivated peripheral blood T cell populations. J. Exp. Med. 158: 571-585.

25. Lane, H. C., G. Whalen, and A. S. Fauci. 1983. Antigeninduced $\mathrm{T}$ cell help: precursor frequency, radiation sensitivity, and allogeneic affects. J. Clin. Invest. 72:636-647.

26. Boyüm, A. 1968. Isolation of mononuclear cells and granulocytes from human blood. Scand. J. Clin. Lab. Invest. 21(Suppl.):77-89.

27. Falkoff, R. J. M., L. P. Zhu, and A. S. Fauci. 1982. Separate signals for human $B$ cell proliferation and differentiation in response to Staphylococcus aureus. Evidence for a two-signal model of B cell activation. J. Immunol. 129:97-102.
28. Reinherz, E. L., P. C. Kung, G. Goldstein, and S. F. Schlossman. 1979. Further characterization of human inducer $T$ cell subsets defined by monoclonal antibody. J. Immunol. 123:2894-2896.

29. Fauci, A. S., G. Whalen, and C. Burch. 1980. Activation of human B lymphocytes. XVI. Cellular requirements, interactions, and immunoregulation of pokeweed mitogen-induced total immunoglobulin producing plaque-forming cells in peripheral blood. Cell. Immunol. 54:215-229.

30. Rabin, H., R. F. Hopkins III, F. W. Ruscetti, R. H. Neubauer, R. L. Brown, and T. G. Kawakami. 1981. Spontaneous release of a factor with properties of $\mathrm{T}$ cell growth factor from a continuous line of primate tumor cells. J. Immunol. 127:1852-1856.

31. Taswell, C. 1981. Limiting dilution assays for the determination of immunocompetent cell frequencies. I. Data analysis. J. Immunol. 126:1614-1619.

32. Volkman, D. J., H. C. Lane, and A. S. Fauci. 1981. Antigeninduced in vitro antibody production in humans: a model for B cell activation and immunoregulation. Proc. Natl. Acad. Sci. USA. 78: 2528-2531.

33. Snedecor, G. W., and W. G. Cochran. 1967. Statistical Methods, 6th Edition. Iowa State University Press, Ames, Iowa. 329-330.

34. Casali, P., G. P. A. Rice, and M. B. S. Oldstone. 1984. Viruses disrupt functions of human lymphocytes: effects of measles virus and influenza virus on lymphocyte-mediated killing and antibody production. J. Exp. Med. 159:1322-1337.

35. Einhorn, L., and $\AA$. Öst. 1984. Cytomegalovirus infection of human blood cells. J. Infect. Dis. 149:207-214.

36. Rice, G. P. A., R. D. Schrier, and M. B. A. Oldstone. 1984. Cytomegalovirus infects human lymphocytes and monocytes: virus expression is restricted to immediate-early gene products. Proc. Natl. Acad. Sci. USA. 81:6134-6138.

37. Gottlieb, M. S., J. E. Groopman, W. M. Weinstein, J. L. Fahey, and R. Detels. 1983. The acquired immunodeficiency syndrome. Ann. Intern. Med. 99:208-220.

38. Robb, R. J., A. Munck, and K. A. Smith. 1981. T cell growth factor receptors. J. Exp. Med. 154:1455-1474.

39. Bernstein, M. L., A. Winkelstein, and S. A. Dobson. 1980. Depressed $\mathrm{T}$ cell colony growth in systemic lupus erythematosus. Arthritis Rheum. 23:385-391.

40. Winkelstein, A., M. L. Bernstein, M. A. Stevens, G. P. Rodnan, T. A. Medsger, and S. A. Dobson. 1982. Reduced T lymphoid colony growth in patients with progressive systemic sclerosis and rheumatoid arthritis. J. Lab. Clin. Med. 100:240-247.

41. Mukhopadhyaya, R., S. H. Advani, and S. G. Gangal. 1983. Impairment of T lymphocyte colony formation in Hodgkin's disease: effect of soluble inhibitory factors on normal $\mathrm{T}$ lymphocyte colony formation potential. Acta Haematol. 70:357-363.

42. Winkelstein A., R. S. Klein, T. L. Evans, B. W. Dixon, W. L. Holder, and L. D. Weaver. 1985. Defective in vitro $T$ cell colony formation in the acquired immunodeficiency syndrome. J. Immunol. 134:151-156.

43. Farcet, J. P., and U. Testa. 1982. Human primary lymphocyte colony formation in agar culture: polyclonal origin and significance. Exp. Hematol. 10:172-177. 